\title{
Intrusion and differentiation of the Tsubashiki diorite stock in the western part of Yamaguchi Prefecture, S.W. Japan \\ - Formation of the stock through fractional crystallization and filter-pressing under a hydrous condition
}

\author{
Masahiko Yamamoto*, Shinko Imayoshi** and Hirotsugu Nishido*** \\ *Department of Earth and Environmental Sciences, Faculty of Science, \\ Kagoshima University, 1-21-35, Korimoto, Kagoshima 890-0065, Japan \\ **Attached Senior High School, Kumamoto Gakuen University, 2-5-1, \\ Oe, Kumamoto 862-0971, Japan \\ *** Research Institute of Natural Sciences, Okayama University of Science, \\ 1201, Kami-fukuda, Kawakami, Maniwa, Okayama 717-0602, Japan
}

\begin{abstract}
The Tsubashiki diorite body in the western part of Yamaguchi Prefecture, Southwest Japan, is a small stock, with comagmatic dikes of various rocks. It is composed of melanocratic hornblende diorite and mesocratic hornblende quartz diorite, with hornblende-pyroxene diorite intruding them. Comagmatic mafic and felsic dikes are accompanied with the diorite stock. The mafic dikes are composed of pyroxene andesite, hornblende andesite and hornblende porphyrite. The felsic dikes are mainly composed of hornblendebearing rocks of tonalite, granodiorite and granite, with minor quartz porphyry. Enclaves of andesitic and dioritic rocks occur in some felsic dikes. The $\mathrm{SiO}_{2}$ content ranges from 52 to $59 \mathrm{wt} . \%$ in the diorite stock, from 55 to 56 wt.\% in the mafic dikes, from 60 to 74 wt.\% in the felsic dikes and from 55 to 59 wt.\% in the andesitic enclaves. The diorite stock, mafic dikes and the andesitic enclaves are rich in $\mathrm{K}_{2} \mathrm{O}$, while the felsic dikes are poor in $\mathrm{K}_{2} \mathrm{O}$ and rich in $\mathrm{Na}_{2} \mathrm{O}$. Whole rock $\mathrm{K}-\mathrm{Ar}$ ages are $82.8 \pm 1.8 \mathrm{Ma}$ for the hornblendepyroxene diorite in the diorite stock and $77.3 \pm 1.7 \mathrm{Ma}$ for the biotite-hornblende granodiorite in the felsic dike, indicating the last stage in the Sanyo-type plutonic activities during Cretaceous in the western Chugoku district.

From field relations, modes of occurrence, petrographical features, $\mathrm{K}-\mathrm{Ar}$ ages and chemical compositions, it is suggested that the Tsubashiki diorite stock was formed by intrusion of a basic andesitic magma under the condition of increase of water and by slight fractional crystallization of ferromagnesian minerals in the hydrous magma. It is also suggested that the mafic dikes were derived from the undifferentiated basic andesitic magma, and that the felsic dikes were formed through filter-pressing differentiation of the residual liquids with magma mixing during the process of cooling of the stock.
\end{abstract}

\section{Introduction}

There are many studies on petrogenesis of the gabbro-

M. Yamamoto, 山本温彦, myama@ sci.kagoshima-u.ac.jp Corresponding author

S. Imayoshi, 今吉伸子

H. Nishido, 西戸裕嗣, nishido@ rins.ous.ac.jp diorite-granite association. They include mainly fractionation of early-formed crystals in a mafic magma (e.g., Wiebe, 1974), magma mixing and mingling between felsic and mafic magmas (e.g., Wiebe, 1973), assimilation or contamination of a felsic magma by mafic rocks (e.g., Vance, 1961), and ultrametamorphism with partial melting of mafic rocks (e.g., White and Chappell, 1977). Such petrogeneses are mostly recog- 
nized in relatively large scale plutons and layered intrusions.

The gabbro-diorite-granite association occurs also in a relatively small scale body derived from a mafic magma. When the water content in the mafic magma will increase in the process of intrusion, the magma will be differentiated through filter-pressing of the residual liquids, and comagmatic mafic enclaves will be enclosed within the filter-pressed liquids through magma mixing.

The Tsubashiki diorite body accompanied by dikes of various rocks is exposed in the western part of Yamaguchi Prefecture, Southwest Japan. Petrological studies of the diorite body and the associated dikes will give a model of magmatic differentiation in a mafic magma. In this paper, geology, mode of occurrence, petrography, $\mathrm{K}-\mathrm{Ar}$ age and chemical composition will be made clear, and processes of intrusion and differentiation will be discussed, for both of the diorite body and the associated dikes.

\section{The Tsubashiki diorite stock}

The Tsubashiki diorite body is located in the coastal area of Hohoku-cho, the western part of Yamaguchi Prefecture. The geology of this area has been reported in the study of the Kanmon Group by Hase (1960). The geologic map of the diorite body is shown in Figure 1.

The diorite body is a small stock exposed in a semi-circular area of about $0.5 \mathrm{~km}^{2}$. It intrudes the

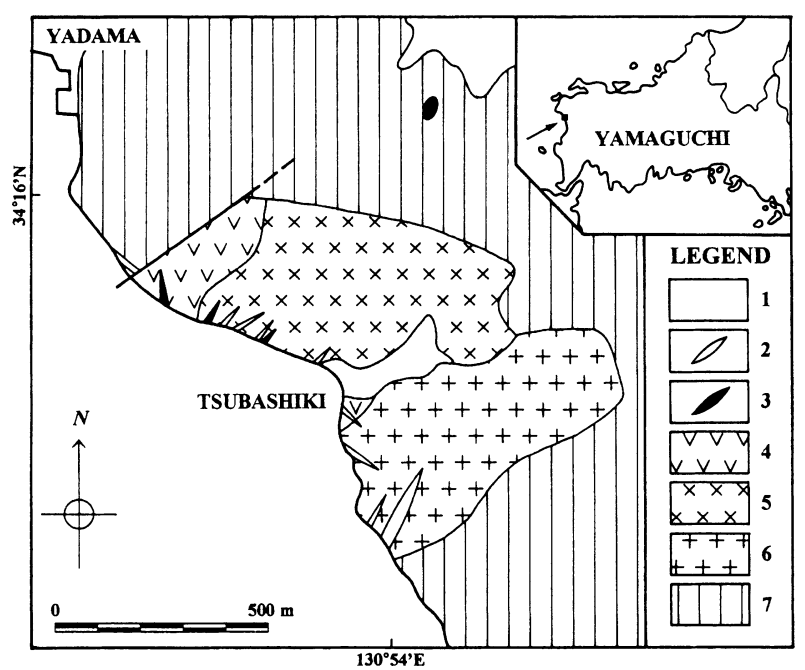

Figure 1. Index and geologic maps of the Tsubashiki diorite stock, Yamaguchi Prefecture. Stratigraphic sequences: 1, Alluvial deposits; 2, Felsic dikes; 3, Mafic dikes; 4, Hornblende-pyroxene diorite; 5, Hornblende diorite; 6, Hornblende quartz diorite; 7, Wakino Subgroup of Kanmon Group.
Wakino Subgroup in the Cretaceous Kanmon Group, composed of mainly terrigenous and volcanic sedimentary rocks. It is composed of melanocratic hornblende diorite in the northern part and mesocratic hornblende quartz diorite in the southern one. A small amount of melanocratic hornblende-pyroxene diorite occurs also in the northwestern and central parts. The relation between the hornblende diorite and the hornblende quartz diorite is gradational, but the hornblende-pyroxene diorite intrudes probably both of them, judged by a slight mylonitized texture near the boundary.

Many dikes of various rocks are accompanied with the diorite stock. They intrude the country rocks and the diorite stock in the northeasterly and northwesterly directions. There are two kinds of dikes of mafic and felsic rocks. The mafic dikes (Fig. 2A) within the stock are composed of hornblende andesite and hornblende porphyrite, and attain a maximum width of about 1 meter. A pyroxene andesite dike intruding the country rocks occurs also in the north of stock. Each of the mafic dikes is homogeneous in mode of occurrence. The felsic dikes (Fig. 2B) within the stock are composed of tonalite, granodiorite and granite, and attain a maximum width of 3 meters. A quartz porphyry dike intruding the country rocks occurs also in the northwest of stock. Each of the felsic dikes varies in mode of occurrence, and structures showing magma mixing and flowage differentiation are found in some felsic dikes, as shown in Figures 2C and 2D, respectively.

Large amounts of comagmatic mafic enclaves are enclosed within some felsic dikes. They show various shapes such as angular, pillow and tabular, indicating that residual liquids caught both of solids and melts, as shown in Figures $2 \mathrm{E}$ and $2 \mathrm{~F}$.

\section{Petrography}

The Tsubashiki diorite stock and the associated dikes are mainly composed of hornblende-bearing rocks. The hornblende diorite in the northern part of stock consists of large amounts of hornblende, clinopyroxene and plagioclase, a small amount of biotite and a minor amount of quartz. The hornblende quartz diorite in the southern part consists of large amounts of hornblende, clinopyroxene and plagioclase and small amounts of biotite and quartz. The later hornblendepyroxene diorite consists of large amounts of clinopyroxene, orthopyroxene, hornblende and plagioclase, a small amount of biotite and a minor amount of quartz.

Clinopyroxene occurs as a coarse-grained and euhedral to subhedral prismatic crystal. It is commonly mantled within hornblende crystals. Orthopyroxene 

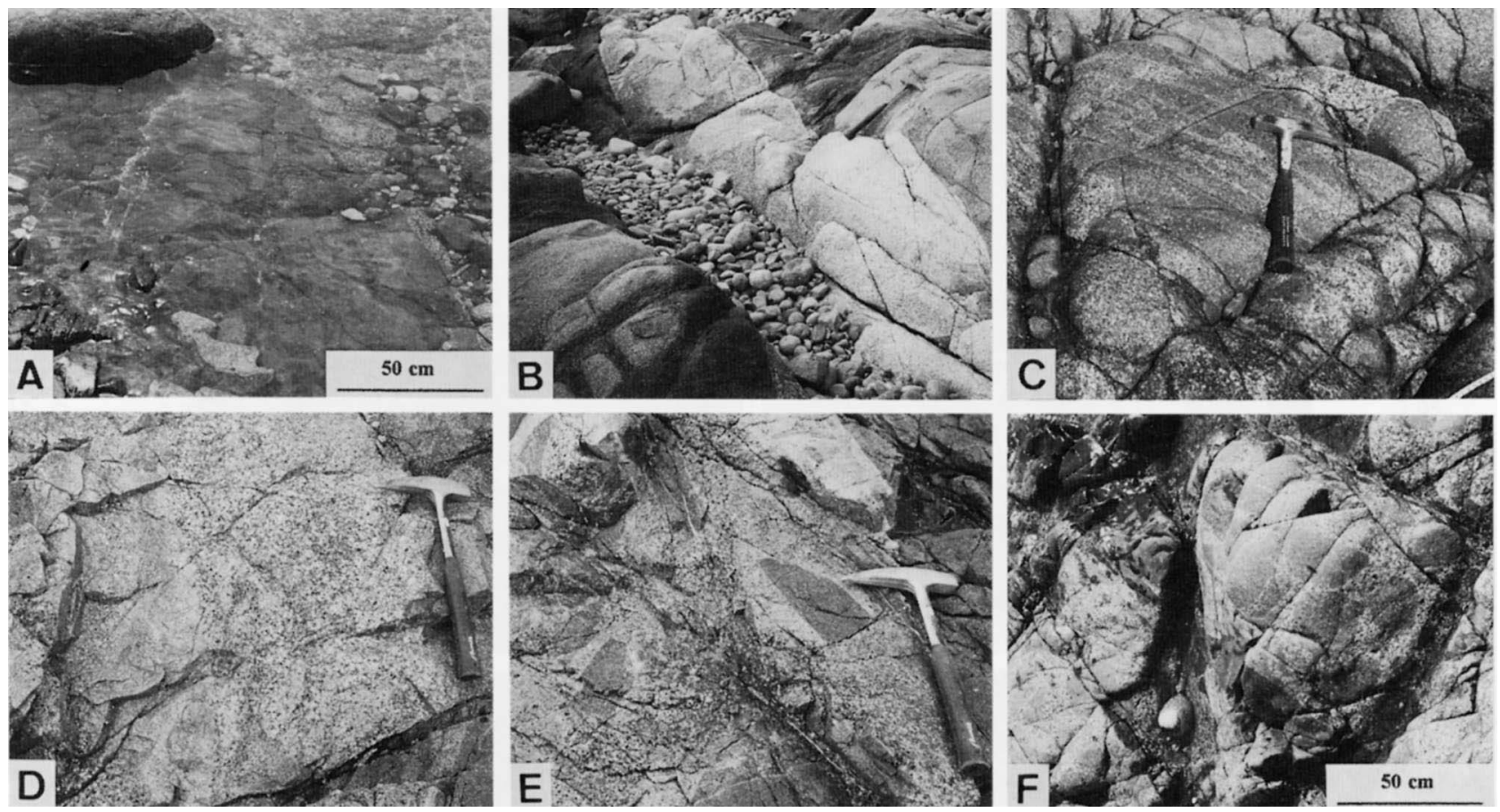

Figure 2. Modes of occurrence of mafic and felsic dikes in the Tsubashiki diorite stock. (A) Hornblende andesite dike. (B) Granodiorite dike. (C) Felsic dike showing magma mixing. (D) Felsic dike showing flowage differentiation. (E) Angularshaped enclaves in the felsic dike. (F) Pillow- and tabular-shaped enclaves in the felsic dike.

occurs as a coarse-grained and euhedral to subhedral prismatic crystal only in the hornblende-pyroxene diorite. It is commonly associated with clinopyroxene crystals. Hornblende occurs as a coarse-grained, green-colored and euhedral to subhedral prismatic crystal. It is often mantled by biotite flakes. Plagioclase occurs as a coarse-grained and euhedral to subhedral prismatic crystal. Albite-type twinned plagioclase is common, but zoned one is rare. Biotite occurs as a medium-grained, brown-colored and subhedral to anhedral flake. Quartz occurs as medium- to finegrained interstitial grains. $\mathrm{K}$-feldspar is rare in the diorites.

The mafic dikes are composed of hornblende andesite, hornblende porphyrite and pyroxene andesite. The hornblende andesite consists of phenocrysts of large amounts of hornblende and plagioclase and a small amount of clinopyroxene, and a hyalo-ophitic groundmass. The hornblende porphyrite consists of phenocrysts of large amounts of hornblende and plagioclase, a small amount of clinopyroxene and minor amounts of biotite and quartz, and a microcrystalline groundmass. It is strongly altered, and mafic minerals are chloritized. The pyroxene andesite dike in the north of stock consists of phenocrysts of large amounts of clinopyroxene, orthopyroxene and plagioclase, and a hyalo-ophitic groundmass.
The felsic dikes are composed of hornblende tonalite, hornblende granodiorite, biotite granodiorite, biotite granite and quartz porphyry. Clinopyroxene, hornblende and plagioclase are abundant in the tonalite, but decrease in amount toward the granite. Clinopyroxene is usually mantled with hornblende crystals. It is rare in the granite and free from the quartz porphyry. Hornblende is sometimes mantled with biotite flakes. It is rare in the quartz porphyry. Biotite is rich in the biotite granodiorite and the biotite granite, but minor in the other felsic dikes. Quartz occurs in all of the felsic dikes, and increases in amount toward the quartz porphyry. $\mathrm{K}$-feldspar is minor in the tonalite, and increases slightly in amount toward the quartz porphyry. Aplitic granite occurs also in the flowage-differentiated felsic dikes (Fig. 2D).

Tabular-shaped enclaves (Fig. 2F) within the felsic dikes are composed of basaltic andesite and andesite. Corroded and rimmed plagioclases are found in these rocks, as shown in Figures $3 \mathrm{~A}$ and $3 \mathrm{~B}$, respectively, indicating that the rocks were formed probably through magma mixing. However, minute flakes of biotite formed by thermal metamorphism are found in their groundmasses, as shown in Figure 3C, indicating that the enclaves were caught as solids. 

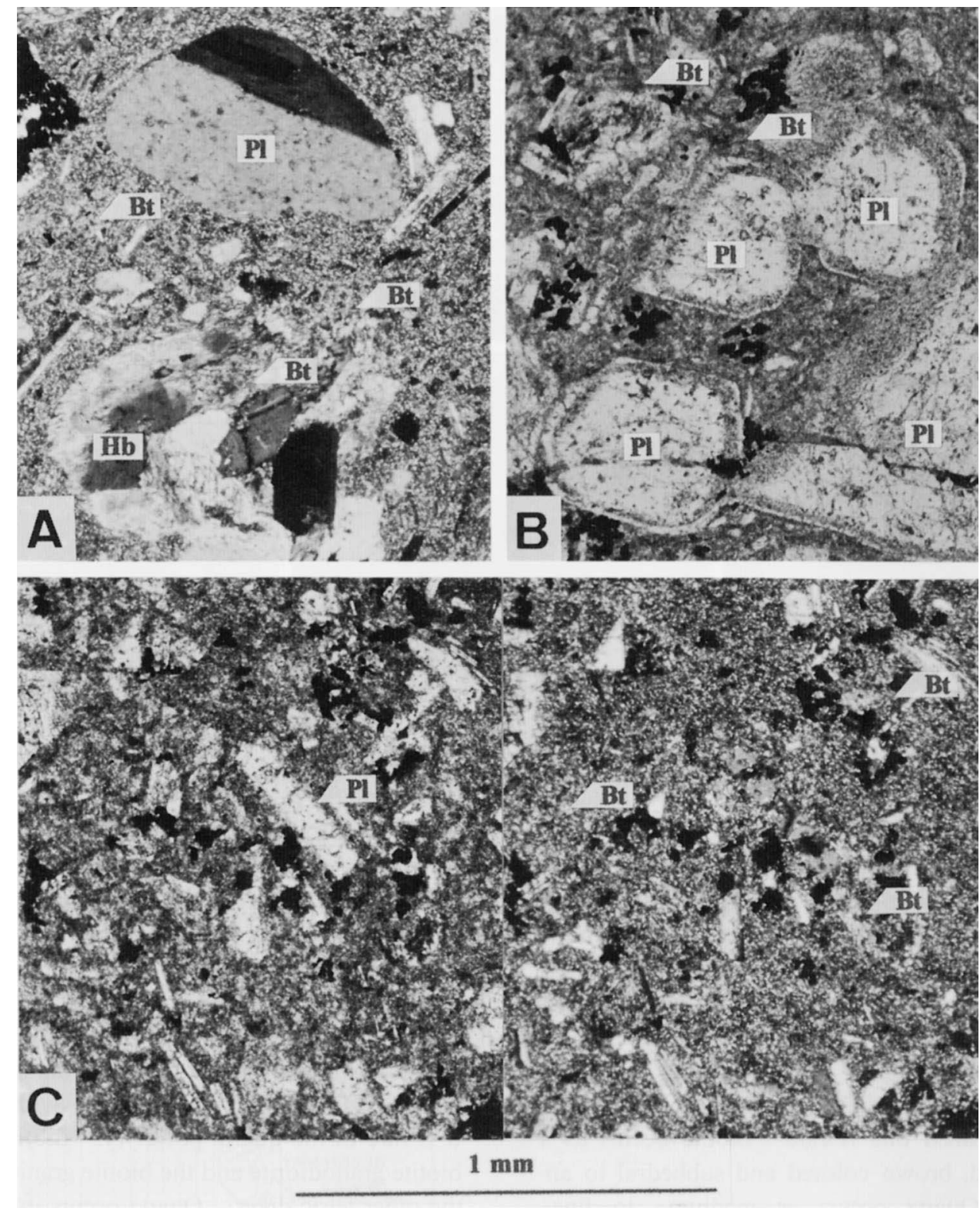

Figure 3. Microphotographs of mafic enclaves in the felsic dikes of Tsubashiki diorite stock. (A) Corroded plagioclase in andesite (crossed nicols). (B) Plagioclases with reaction rims in andesite (open nicol). (C) Thermally metamorphosed basaltic andesite (left: open nicol; right: crossed nicols). Abbreviations: $\mathrm{Pl}$, plagioclase; $\mathrm{Hb}$, hornblende; $\mathrm{Bt}$, biotite.

\section{Chemical composition}

Chemical analyses were carried out for the Tsubashiki diorite stock, associated dikes and the andesitic enclaves within the felsic dikes. They were determined by a combination of atomic absorption (Terashima, 1971, 1973) and gravimetric methods. The results are listed in Table 1, and variation diagrams are shown in Figure 4.

The hornblende diorite in the northern part of stock ranges in $\mathrm{SiO}_{2}$ from 52 to $54 \mathrm{wt. \%}$, showing to have the most basic composition in the stock. The horn- blende quartz diorite in the southern part ranges from 57 to $59 \mathrm{wt} . \%$, and the later hornblende-pyroxene diorite ranges from 54 to $56 \mathrm{wt} . \%$. The $\mathrm{SiO}_{2}$ content of mafic dikes ranges from 55 to $59 \mathrm{wt} . \%$, and is similar to that of diorite stock. That of felsic dikes ranges from 61 to 74 wt.\%, showing a wide variation. The andesitic enclaves within the felsic dikes range in $\mathrm{SiO}_{2}$ from 56 to 59 wt.\%, and are similar to the diorite stock and the mafic dikes.

As seen in Figure 4, the chemical composition varies linearly from the diorite stock and the mafic dikes to the felsic dikes. The diorite stock and the mafic dikes are rich in $\mathrm{K}_{2} \mathrm{O}$, while the felsic dikes are poor in 
Table 1. Chemical analyses of the Tsubashiki diorite stock

\begin{tabular}{|c|c|c|c|c|c|c|c|c|c|c|}
\hline $\begin{array}{l}\text { Sp.No. } \\
\text { Occur. } \\
\text { Rock } \\
\end{array}$ & $\begin{array}{c}9680713 \\
\text { Stock } \\
\text { HD }\end{array}$ & $\begin{array}{c}9680705 \\
\text { Stock } \\
\text { HD }\end{array}$ & $\begin{array}{c}9680813 \\
\text { Stock } \\
\text { HQD }\end{array}$ & $\begin{array}{c}9680820 \\
\text { Stock } \\
\text { HQD }\end{array}$ & $\begin{array}{c}9680609 \\
\text { Stock } \\
\text { HPD }\end{array}$ & $\begin{array}{c}9680607 \\
\text { Stock } \\
\text { HPD }\end{array}$ & $\begin{array}{l}95 \mathrm{C} 0904 \\
\text { Stock } \\
\text { HPD }\end{array}$ & $\begin{array}{l}\text { 95C0909 } \\
\text { Stock } \\
\text { HPD }\end{array}$ & $\begin{array}{c}9680612 \\
\text { Dike } \\
\text { HA }\end{array}$ & $\begin{array}{c}95 \mathrm{C} 1009 \\
\text { Dike } \\
\text { PA }\end{array}$ \\
\hline $\mathrm{SiO}_{2}$ & 51.77 & 53.79 & 56.99 & 58.65 & 55.42 & 56.15 & 53.88 & 55.62 & 55.44 & 55.97 \\
\hline $\mathrm{TiO}_{2}$ & 1.15 & 1.05 & 0.85 & 1.05 & 0.99 & 1.05 & 1.15 & 1.28 & 0.78 & 0.92 \\
\hline $\mathrm{Al}_{2} \mathrm{O}_{3}$ & 19.27 & 17.01 & 18.20 & 17.21 & 17.16 & 17.33 & 16.78 & 15.13 & 17.66 & 17.90 \\
\hline $\mathrm{Fe}_{2} \mathrm{O}_{3}{ }^{*}$ & 9.51 & 9.42 & 7.79 & 7.50 & 8.99 & 8.68 & 10.54 & 11.03 & 8.56 & 8.36 \\
\hline $\mathrm{MnO}$ & 0.17 & 0.19 & 0.13 & 0.14 & 0.15 & 0.16 & 0.21 & 0.19 & 0.13 & 0.16 \\
\hline $\mathrm{MgO}$ & 4.12 & 4.99 & 3.39 & 3.03 & 3.50 & 3.77 & 4.93 & 5.90 & 4.17 & 3.65 \\
\hline $\mathrm{CaO}$ & 8.43 & 8.13 & 7.67 & 6.25 & 7.37 & 7.26 & 7.97 & 5.76 & 7.54 & 7.64 \\
\hline $\mathrm{Na}_{2} \mathrm{O}$ & 2.82 & 2.93 & 3.09 & 3.28 & 3.41 & 3.28 & 2.21 & 2.15 & 3.20 & 2.95 \\
\hline $\mathrm{K}_{2} \mathrm{O}$ & 0.65 & 0.84 & 0.86 & 1.87 & 1.41 & 1.50 & 1.67 & 1.79 & 0.70 & 1.21 \\
\hline $\mathrm{H}_{2} \mathrm{O}^{+}$ & 1.75 & 1.24 & 1.03 & 1.17 & 1.22 & 0.74 & 0.54 & 1.16 & 1.74 & 1.05 \\
\hline $\mathrm{H}_{2} \mathrm{O}^{-}$ & 0.19 & 0.15 & 0.14 & 0.08 & 0.18 & 0.09 & 0.14 & 0.02 & 0.12 & 0.06 \\
\hline $\mathrm{P}_{2} \mathrm{O}_{5}$ & 0.11 & 0.09 & 0.10 & 0.10 & 0.15 & 0.10 & 0.10 & 0.16 & 0.12 & 0.12 \\
\hline Total & 99.94 & 99.83 & 100.24 & 100.33 & 99.95 & 100.11 & 100.12 & 100.19 & 100.16 & 99.99 \\
\hline Sp.No. & 9680703 & 9680811 & $95 \mathrm{C} 0917 \mathrm{~A}$ & $95 \mathrm{C} 0902$ & $95 \mathrm{C} 1008$ & 9680708 & 9680610 & $95 \mathrm{C} 0917 \mathrm{~B}$ & 9680818 & 9680817 \\
\hline Occur. & Dike & Dike & Dike & Dike & Dike & Dike & Dike & Dike & Enclave & Enclave \\
\hline Rock & $\mathrm{HPO}$ & TO & GD & GD & GD & GR & QP & $\mathrm{AG}$ & $\mathrm{HA}$ & $\mathrm{HA}$ \\
\hline $\mathrm{SiO}_{2}$ & 59.21 & 60.64 & 63.69 & 65.32 & 66.32 & 67.97 & 73.05 & 74.33 & 55.50 & 59.37 \\
\hline $\mathrm{TiO}_{2}$ & 0.60 & 0.66 & 0.53 & 0.46 & 0.69 & 0.32 & 0.18 & 0.41 & 0.69 & 1.05 \\
\hline $\mathrm{Al}_{2} \mathrm{O}_{3}$ & 16.47 & 15.36 & 16.65 & 16.75 & 15.90 & 15.03 & 15.26 & 13.63 & 17.53 & 18.08 \\
\hline $\mathrm{Fe}_{2} \mathrm{O}_{3} *$ & 8.04 & 7.53 & 4.52 & 3.52 & 3.79 & 3.84 & 1.78 & 1.31 & 9.09 & 6.16 \\
\hline $\mathrm{MnO}$ & 0.26 & 0.10 & 0.06 & 0.05 & 0.04 & 0.04 & 0.03 & 0.02 & 0.07 & 0.06 \\
\hline $\mathrm{MgO}$ & 3.11 & 3.03 & 1.97 & 1.37 & 1.09 & 1.09 & 0.17 & 0.44 & 3.92 & 2.72 \\
\hline $\mathrm{CaO}$ & 2.67 & 5.27 & 5.62 & 5.29 & 3.45 & 2.97 & 0.82 & 3.51 & 7.29 & 4.97 \\
\hline $\mathrm{Na}_{2} \mathrm{O}$ & 2.86 & 3.52 & 4.03 & 3.98 & 3.99 & 4.42 & 4.62 & 3.72 & 3.46 & 2.61 \\
\hline $\mathrm{K}_{2} \mathrm{O}$ & 4.19 & 1.66 & 1.16 & 1.97 & 2.46 & 1.58 & 2.57 & 1.10 & 1.54 & 2.11 \\
\hline $\mathrm{H}_{2} \mathrm{O}^{+}$ & 2.68 & 1.78 & 1.16 & 1.22 & 1.92 & 2.00 & 1.12 & 0.90 & 0.66 & 2.28 \\
\hline $\mathrm{H}_{2} \mathrm{O}^{-}$ & 0.10 & 0.20 & 0.18 & 0.24 & 0.19 & 0.32 & 0.08 & 0.14 & 0.04 & 0.12 \\
\hline $\mathrm{P}_{2} \mathrm{O}_{5}$ & 0.09 & 0.13 & 0.08 & 0.10 & 0.09 & 0.05 & 0.10 & 0.06 & 0.09 & 0.10 \\
\hline Total & 100.28 & 99.88 & 99.65 & 100.27 & 99.94 & 99.63 & 99.78 & 99.63 & 99.88 & 99.63 \\
\hline
\end{tabular}

*Total $\mathrm{Fe}$ as $\mathrm{Fe}_{2} \mathrm{O}_{3}$.

Rocks: HD, hornblende diorite; HQD, hornblende quartz diorite; HPD, hornblende-pyroxene diorite; HA, hornblende andesite; PA, pyroxene andesite; HPO, hornblende porphyrite; TO, tonalite; GD, granodiorite; GR, granite; QP, quartz porphyry; AG, aplitic granite.

$\mathrm{K}_{2} \mathrm{O}$ and rich in $\mathrm{Na}_{2} \mathrm{O}$, as compared to the average chemical composition of Japanese granitoids reported by Aramaki et al. (1972). Such the chemical variation in $\mathrm{K}_{2} \mathrm{O}$ is due to the modal composition of biotite. The altered porphyrite is exceptionally rich in $\mathrm{K}_{2} \mathrm{O}$ and poor in $\mathrm{CaO}$.

\section{K-Ar age}

Whole rock $\mathrm{K}-\mathrm{Ar}$ ages were measured for the hornblende-pyroxene diorite in the Tsubashiki diorite stock and the biotite-hornblende granodiorite in the associated felsic dikes. They were determined by a mass spectrometer of Okayama University of Science (Nagao et al., 1984). The results are listed in Table 2.

The $\mathrm{K}-\mathrm{Ar}$ ages indicate $82.8 \pm 1.8 \mathrm{Ma}$ for the diorite and $77.3 \pm 1.7 \mathrm{Ma}$ for the granodiorite, and are in accord with their field relations. The granodiorite is 5.5 Ma younger in age than the diorite, but it can be considered that both are products of contemporaneous igneous activity, judged by their analytical errors, $2 \sigma$.

\section{Discussion}

The Cretaceous Sanyo-type granitoids are widely distributed in the western part of Yamaguchi Prefecture (Murakami and Imaoka, 1986; Nishimura et al., 1995). The whole rock $\mathrm{K}-\mathrm{Ar}$ ages of the Tsubashiki diorite stock and the felsic dike are $82.8 \mathrm{Ma}$ and $77.3 \mathrm{Ma}$, respectively. It has been reported that the biotite $\mathrm{K}-\mathrm{Ar}$ ages are 90.6 Ma and 90.7 Ma for the Kanda granodiorite (Takeshita Consultant, 1992, cited from Nishimura and Imaoka, 1995) and the Kogushi granodiorite (Murakami and Imaoka, 1986), respectively, in the surrounding 


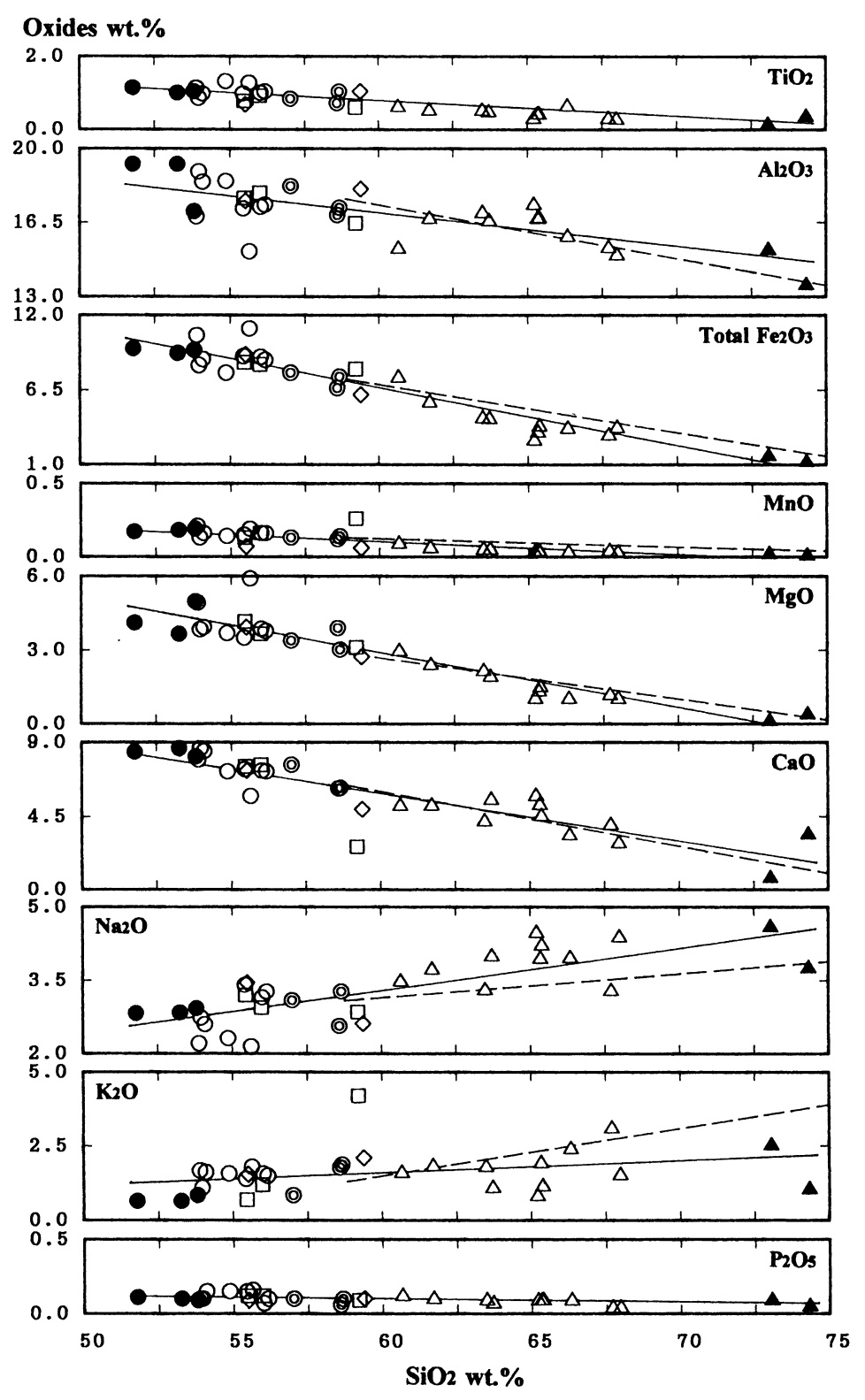

Figure 4. Variation diagrams of the Tsubashiki diorite stock. Solid lines represent linear regression curves for the stock, and dashed ones for the average composition of Japanese granitoids after Aramaki et al. (1972).

Symbols: ๑, hornblende diorite; $\odot$, hornblende quartz diorite; $\bigcirc$, hornblende-pyroxene diorite; $\square$, mafic dikes; $\triangle$, tonalite to granite in the felsic dikes; $\Delta$, quartz porphyry and aplitic granite in the felsic dikes; $\diamond$, enclaves within the felsic dikes.

Table 2. Whole rock $\mathrm{K}-\mathrm{Ar}$ ages of the Tsubashiki diorite stock

\begin{tabular}{llllll}
\hline No. Sample & $\begin{array}{l}\mathrm{K} \text {-Ar age } \\
(\mathrm{Ma} \pm \sigma)\end{array}$ & $\begin{array}{l}\mathrm{K} \\
(\mathrm{wt} \% \%)\end{array}$ & $\begin{array}{l}\mathrm{Rad}^{40} \mathrm{Ar} \\
\left(10^{-9} \mathrm{ccSTP} / \mathrm{g} \pm \sigma\right)\end{array}$ & $\begin{array}{l}\mathrm{AirAr} \\
(\%)\end{array}$ \\
\hline 1 & Whole rock & $82.8 \pm 1.8$ & 1.21 & $396.6 \pm 4.2$ & 11.2 \\
2 & Whole rock & $77.3 \pm 1.7$ & 1.71 & $523.8 \pm 5.8$ & 12.7 \\
\hline
\end{tabular}

$\lambda_{\mathrm{e}}=0.581 \times 10^{-10} / \mathrm{yr}$., $\lambda_{\beta}=4.962 \times 10^{-10} / \mathrm{yr} .,{ }^{40} \mathrm{~K} / \mathrm{K}=0.0001167$. No. 1: Hornblende-pyroxene diorite (Sp. No. 95C0904) from the diorite stock.

No. 2: Biotite-hornblende granodiorite (Sp. No. 95C0902) from the felsic dike. areas of Tsubashiki. These $\mathrm{K}-\mathrm{Ar}$ ages indicate that the Tsubashiki diorite stock is younger than the surrounding granitic bodies. It has been also reported that the biotite $\mathrm{K}-\mathrm{Ar}$ age is $81 \mathrm{Ma}$ for quartz diorite (Kawano and Ueda, 1966; recalculated by Murakami and Imaoka, 1986) and the zircon fission-track age is $78.4 \mathrm{Ma}$ for aplitic granite (Ueda and Nishimura, 1982) in the Heki area, about $27 \mathrm{~km}$ northeast of Tsubashiki. These radiogenic ages indicate also that the similar intrusive bodies to the Tsubashiki diorite stock are sparsely distributed in the western part of Yamaguchi Prefecture. Furthermore, the Cretaceous plutonic activities in the western Chugoku district range from 75 to $110 \mathrm{Ma}$, as reported by Murakami (1985) and Murakami and Imaoka (1986). Thus, it is indicated that the Tsubashiki 


\section{Total $\mathrm{Fe}_{2} \mathrm{O} 3$}

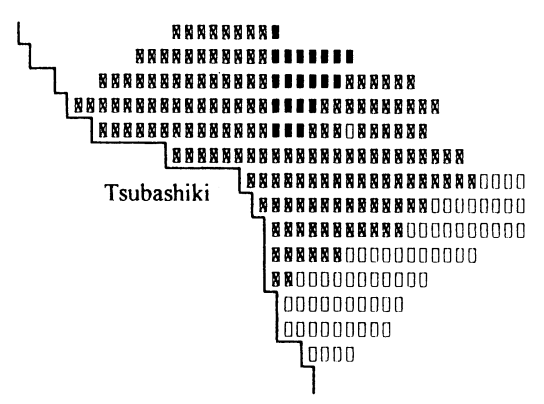

MgO

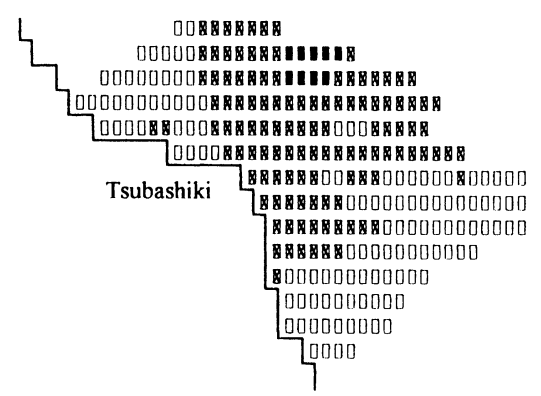

$\mathrm{CaO}$

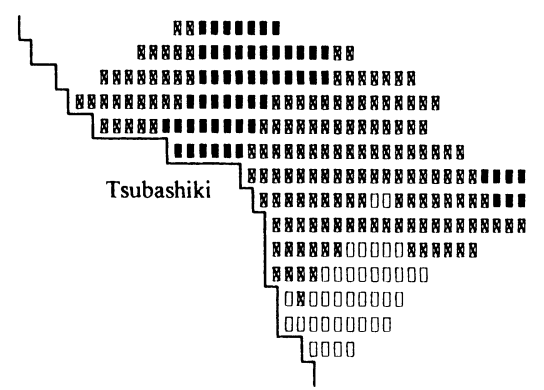

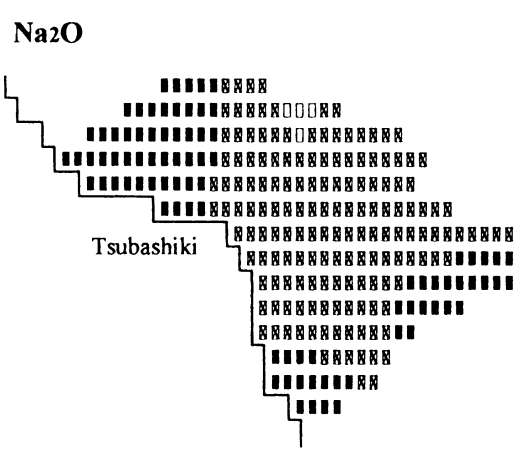

$\mathrm{K} 2 \mathrm{O}$

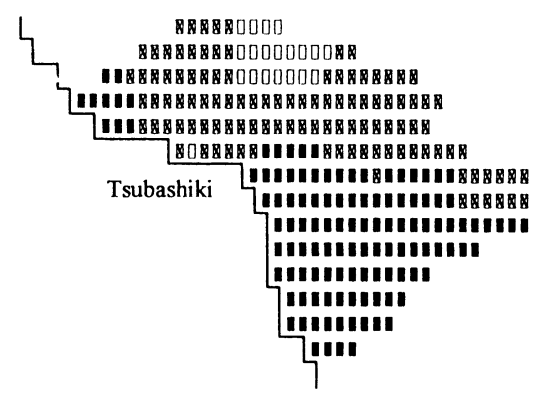

LEGEND

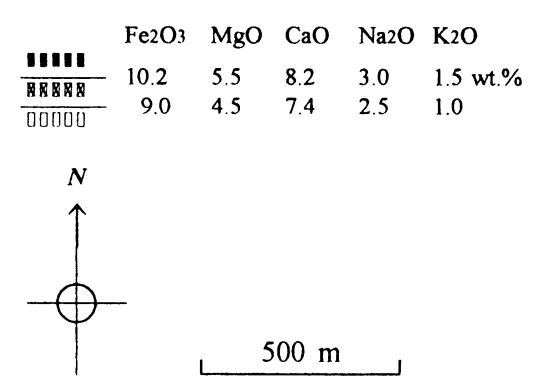

Figure 5. Grid chemical maps for total $\mathrm{Fe}_{2} \mathrm{O}_{3}, \mathrm{MgO}, \mathrm{CaO}, \mathrm{Na}_{2} \mathrm{O}$ and $\mathrm{K}_{2} \mathrm{O}$ of the Tsubashiki diorite stock.

diorite stock is a product of the last stage in the Cretaceous plutonic activities.

The Tsubashiki diorite stock ranges in $\mathrm{SiO}_{2}$ from 52 to 59 wt.\%. Grid chemical maps for total $\mathrm{Fe}_{2} \mathrm{O}_{3}$, $\mathrm{MgO}, \mathrm{CaO}, \mathrm{Na}_{2} \mathrm{O}$ and $\mathrm{K}_{2} \mathrm{O}$ of the diorite stock are shown in Figure 5. As seen in Figure 5, slight compositional variations for all oxides can be recognized in the diorite stock. The hornblende diorite in the northern part of stock is slightly basic, compared to the hornblende quartz diorite in the southern one. The later hornblende-pyroxene diorite has the intermediate composition between them. It has the same composition as the andesites in the mafic dikes. The mineral and chemical compositions of these rocks suggest that the intruded magma was originally pyroxene andesitic, that pyroxenes were decomposed to hornblende under the condition of increase of water, and that the hornblende diorite and the hornblende quartz diorite were separated from each other through slight fractional crystallization of ferromagnesian minerals in the hydrous magma. Thus, the diorite stock shows a sequence from the hornblende quartz diorite through the hornblende diorite to the hornblende-pyroxene diorite, in ascending order, and the sequence is not contradictory with their field relations.

Most of dikes occur in the diorite stock, as seen in Figure 1. The mafic dikes have the same composition as the later hornblende-pyroxene diorite in the diorite stock. These facts suggest that they are comagmatic with the diorite stock, and were derived from the undifferentiated basic andesitic magma.

Magma mixing with mafic melts is found in some felsic dikes, as shown in Figure 2C. Also, the tabularshaped andesitic enclaves within the felsic dikes contain corroded and rimmed plagioclases formed through probably magma mixing, as shown in Figures $3 \mathrm{~A}$ and 3B. On the other hand, the felsic dikes have the continuous compositional variation ranging from the tonalite 
through the granodiorite and granite to the quartz porphyry, as seen in Figure 4. The aplitic granite formed by flowage differentiation has also the similar composition to the quartz porphyry. These modes of occurrence and chemical compositions suggest that the felsic dikes are comagmatic with the diorite stock, as well as the mafic ones. Furthermore, the felsic dikes include the mafic enclaves derived from not only solidified dioritic rocks but also unsolidified mafic melts, as shown in Figures $2 \mathrm{E}$ and $2 \mathrm{~F}$. These facts suggest, therefore, that the felsic dikes were formed by differentiation through filter pressing of residual liquids into the diorite stock, as filter differentiation reported by Propach (1976), and through magma mixing of the residual liquids with dioritic rocks and mafic melts in the process of filter pressing.

As mentioned above, it can be summarized that the Tsubashiki diorite stock was formed by the intrusion of basic andesitic magma under the condition of increase of water and by slight fractional crystallization of ferromagnesian minerals in the hydrous magma, and that the comagmatic felsic dikes were formed through filterpressing differentiation of the residual liquids with magma mixing in the process of cooling of the stock.

\section{Acknowledgments}

The authors wish to thank Dr. T. Imaoka of Yamaguchi University for his valuable comments. They are also indebted to the co-editor, Dr. M. Murata of Naruto University of Education, and the referees, Dr. A. Takada of Geological Survey of Japan and Dr. R. Anma of Tsukuba University, for critical reading of the manuscript and valuable suggestions.

\section{References}

Aramaki, S., Hirayama, K. and Nozawa, T. (1972) Chemical composition of Japanese granites, Part 2. Variation trends and average composition of 1200 analyses. Journal of Geological Society of Japan, 78, 39-49.

Hase, A. (1960) The Late Mesozoic formations and their molluscan fossils in West Chugoku and North Kyushu, Japan. Journal of Science of Hiroshima University, Ser. C, 3, 281-342

Kawano, Y. and Ueda, Y. (1966) K-Ar dating on the igneous rocks in Japan (V). Granitic rocks in southwestern Japan. Journal of Japanese Association of Mineralogists,
Petrologists and Economic Geologists, 56, 191-211.

Murakami, N. (1985) Late Mesozoic to Paleogene igneous activity in West Chugoku, Southwest Japan. Journal of Geological Society of Japan, 91, 723-742.

Murakami, N. and Imaoka, T. (Eds.) (1986) Acid to intermediate igneous activity in West Chugoku and its adjacent areas, Southwest Japan. Journal of Faculty of Liberal Arts, Yamaguchi University, Professor Nobuhide Murakami Memorial Volume, pp. 419.

Nagao, K., Nishido, H., Itaya, T. and Ogara, K. (1984) An age determination by $\mathrm{K}$-Ar method. Bulletin of Hiruzen Research Institute, Okayama University of Science, No. 9, 19-38.

Nishimura, Y. and Imaoka, T. (Eds.) (1995) Map of radiogenic ages in Yamaguchi Prefecture, $1: 150,000$, and the explanatory text entitled in "Radiogenic ages in Yamaguchi Prefecture (Summary in 1994)". Association of Earth Sciences of Yamaguchi Prefecture, pp. 13.

Nishimura, Y., Imaoka, T., Utamura, Y. and Kameya, A. (Eds.) (1995) Revised geological map of Yamaguchi Prefecture, 1:150,000. Association of Earth Sciences of Yamaguchi Prefecture.

Propach, G. (1976) Models of filter differentiation. Lithos, 9, 203-209.

Takeshita Consultant (1992) Exploitation of spring water resources in Hohoku-cho (the second and third reports). Hohoku-cho, pp. 76.

Terashima, S. (1971) Determination of sodium, potassium, magnesium, calcium, manganese and iron in the silicate rocks and terrestrial water by atomic absorption spectrophotometry. Bulletin of Geological Survey of Japan, 21, 693-707.

Terashima, S. (1973) Analyses of silicates by atomic absorption spectrophotometry in a nitrous oxide-acetylene flame. Bulletin of Geological Survey of Japan, 23, 287-304.

Ueda, K. and Nishimura, Y. (1982) Stratigraphic successions and fission-track ages of late Cretaceous volcanic rocks distributed in the Agawa-Yumoto and Oumi Island districts. Abstract of 89th Annual Meeting, Geological Society of Japan, 382.

Vance, J.A. (1961) Zoned granitic intrusions. An alternative hypothesis of origin. Bulletin of Geological Society of America, 72, 1723-1727.

White, A.J.R. and Chappell, B.W. (1977) Ultrametamorphism and granitoid genesis. Tectonophysics, 43, 7-22.

Wiebe, R.A. (1973) Relations between coexisting basaltic and granitic magmas in a composite dike. American Journal of Science, 273, 130-151.

Wiebe, R.A. (1974) Differentiation in layered diorite intrusions, Ingonish, Nova Scotia. Journal of Geology, 82, $731-750$.

Manuscript received; 21 June, 1999

Manuscript accepted; 31 May, 2000 